\title{
Collagen supplementation as a complementary therapy for the prevention and treatment of osteoporosis and osteoarthritis: a systematic review
}

\section{Abstract}

Introduction: Collagen hydrolysate is recognized as a safe nutraceutical, whose combination of amino acids stimulates the synthesis of collagen in the extracellular matrix of cartilage and other tissues. Objective: to conduct a systematic review of literature on the action of collagen hydrolysate in bone and cartilaginous tissue and its therapeutic use against osteoporosis and osteoarthritis. Method: a study of the PubMed, MEDLINE, LILACS, and SciELO databases was performed. Articles published in English and Portuguese in the period of 1994 to 2014 were considered. Results: the sample comprised nine experimental articles with in vivo (animals and humans) and in vitro (human cells) models, which found that the use of different doses of collagen hydrolysate were associated with the maintenance of bone composition and strength, and the proliferation and cell growth of cartilage. Conclusion: hydrolyzed collagen has a positive therapeutic effect on osteoporosis and osteoarthritis with a potential increase in bone mineral density, a protective effect on articular cartilage, and especially in the symptomatic relief of pain.
Key word: Collagen; Osteoarthritis; Osteoporosis; Elderly.

Universidade Estácio de Sá, Programa de Pós-graduação em Nutrição Clínica: metabolismo, prática e terapia nutricional. São José dos Campos, SP, Brasil.

Elisângela Porfírio Gustavo Bernardes Fanaro' 


\section{INTRODUCTION}

The human body goes through several stages: childhood, puberty, maturity or stabilization and then aging. Aging occurs through several changes, and begins as early as the second decade of life. At first, these changes are barely noticeable, but by the end of the third decade many important functional and/or structural changes have taken place'.

Evidence indicates that many chronic diseases result from the interaction of various factors, including genetic, environmental and lifestyle. Those that are classified as modifiable include: smoking, alcohol intake, eating habits, a sedentary lifestyle, stress, while those classified as not modifiable are heredity, gender and age. ${ }^{2}$

Osteoporosis (OP) constitutes a disease of the skeleton of multifactorial cause that is characterized by reduced bone mass and deterioration of the anatomical and structural integrity of the bones, leading to increased bone fragility and susceptibility to fracture. The group most affected by OP are older women whose decreased estrogen production after menopause accelerates bone loss. ${ }^{3}$

Among joint diseases, osteoarthritis (OA) is the most prevalent and evolves slowly over decades, manifesting itself in episodes of pain and culminating in the loss of joint function. Inconclusive studies indicate that bone changes can initiate or influence the degradation of cartilage. Despite many efforts, there is so far no cure for $\mathrm{OA}$, and the treatments available, both pharmacological and non-pharmacological, only act in reducing the symptoms, especially pain, inflammation and immobility. ${ }^{4,5}$

Nutraceuticals are substances which can act as adjuvants in the prevention and treatment of chronic diseases, in particular OA. The term nutraceutical comes from the combination of the words "nutrition" and "pharmaceutical". It corresponds to foods or products that not only provide health benefits, but are also, by definition and regulation, devoid of adverse effects. Collagen hydrolysate $(\mathrm{CH})$ is recognized as a safe food with minimal adverse effects, whose amino acid composition provides elevated levels of glycine and proline, which accumulate when properly digested, preferentially in cartilage. ${ }^{4}$

Both aging and a poor diet can affect the level of collagen in the body. These changes are not noticeable in the early stages of life, but become evident in the mature phase, in which food intake does not meet the recommended requirements as effectively, in terms of energy and macro and micronutrients. ${ }^{6}$ Also at this stage the chances of developing bone and joint disorders are higher. Balanced nutrition is essential not only for preventing chronic diseases, but also for maintaining a healthy body and ensuring its proper functioning. ${ }^{7}$

Thus, the aim of this study was to perform a systematic review of literature on the action of collagen hydrolysate in bone and cartilage tissue, and its therapeutic effects on osteoporosis and osteoarthritis.

\section{METHOD}

A systematic review of literature was carried out, focusing on scientific articles that studied the action of collagen hydrolysate on cartilage and bone, as well as their possible therapeutic support in cases of osteoarthritis and osteoporosis. The PubMed, MEDLINE, LILACS and SciELO databases were consulted, and the descriptors used for research were collagen bydrolysate, combined with osteoporosis, osteoarthritis, bone, cartilage, aging, ingestion and supplement. The search period was from January 1994 to May 2014. The review was conducted from January to May 2014.

The inclusion criteria were: experimental articles, in English and Portuguese, published between January 1994 and May 2014, with the object of study the action of collagen hydrolysate in bone and cartilage tissue as well as its therapeutic effects in osteoporosis and osteoarthritis. Excluded from the search were meta-analyses, notes, case reports, theses; articles involving other causes of 
bone and/or joint disease; articles that combined drugs with oral supplementation of collagen; and duplicated items indexed in more than one of the selected databases.

The process for inclusion of articles in the study involved the reading the titles and abstracts by two independent reviewers, who applied the inclusion and exclusion criteria. In case of disagreement, the study was selected for evaluation of the full text.

\section{RESULTS}

The initial search, based on a combination of terms, identified 187 articles. After verification of the existence of duplicity, 57 were excluded. Considering the titles and abstracts based on a wide selection of work that would likely be of interest, 62 articles were excluded, leaving 68 studies, 47 in PubMed and 21 in MEDLINE, LILACS and SciELO. Articles that met the eligibility criteria were retrieved so the full text could be read, with a view to further evaluation. At this stage 59 publications were excluded that did not meet the purpose of this research.

Nine experimental articles were identified as the basis for discussion in this review. The nine included: five research articles with human models, three with animal models, and one that evaluated, respectively, in vitro models (human cells) and animal models.

Table 1 presents the experimental data of the articles included in this systematic review.

Table 1. Distribution of articles according to author, sample, method, results and conclusion. May, 2014.

\begin{tabular}{|c|c|c|c|c|}
\hline Author & Sample & Method & Results & Conclusion \\
\hline Hays et al. ${ }^{24}$ & $\begin{array}{l}\text { Humans: } \\
\text { nine elderly } \\
\text { women } \\
\text { (between } 65-85 \\
\text { years of age) }\end{array}$ & $\begin{array}{l}\text { Whey protein }(0.85 \\
\mathrm{g} / \mathrm{kg} / \text { weight/day }) \\
15 \text { days } \\
\mathrm{CH}(0,81 \mathrm{~g} / \mathrm{kg} / \\
\text { weight } / \text { day }) \\
15 \text { days }\end{array}$ & $\begin{array}{l}\text { Whey protein group: } \\
\text { Lower weight; } \\
\text { higher excretion of } \\
\text { nitrogen } \\
\text { CH group: } \\
\text { Maintaining of weight; } \\
\text { Lower excretion of } \\
\text { nitrogen }\end{array}$ & $\begin{array}{l}\text { Maintaining } \\
\text { of weight and } \\
\text { muscle mass }\end{array}$ \\
\hline $\begin{array}{l}\text { Guillerminet et } \\
\text { al. } .^{26}\end{array}$ & $\begin{array}{l}\text { In vivo } \\
\text { Mice }\end{array}$ & $\begin{array}{l}\mathrm{CH} 10 \text { or } 25 \mathrm{~g} / \mathrm{kg} / \\
\text { weight } / \text { day } \\
4-12 \text { weeks } \\
\text { Bone mineral } \\
\text { density }\end{array}$ & $\begin{array}{l}\text { Higher growth and } \\
\text { differentiation of } \\
\text { osteoblasts; } \\
\text { higher growth and } \\
\text { differentiation of } \\
\text { osteoclasts }\end{array}$ & $\begin{array}{l}\text { Osteoprotective } \\
\text { action }\end{array}$ \\
\hline Jackix et al. ${ }^{27}$ & Rats, six groups & $\begin{array}{l}\text { CH } 50 \text { mg; } 100 \text { mg, } \\
\text { control (gelatin) } \\
\text { Sample of femur } \\
\text { and vertebral } \\
\text { column. }\end{array}$ & $\begin{array}{l}\text { Supported weight four- } \\
\text { times heavier; } \\
\text { Higher percentage of bone } \\
\text { protein; } \\
\text { Higher bone } \\
\text { mineralization }\end{array}$ & $\begin{array}{l}\text { Greater } \\
\text { conservation of } \\
\text { the composition } \\
\text { and bone } \\
\text { strength }\end{array}$ \\
\hline
\end{tabular}




\begin{tabular}{|c|c|c|c|c|}
\hline Author & Sample & Method & Results & Conclusion \\
\hline \multirow[b]{2}{*}{ Kim et al. ${ }^{28}$} & $\begin{array}{l}\text { In vitro } \\
\text { Human cells }\end{array}$ & Gene COL1A1 & $\begin{array}{l}\text { Increased osteoblast } \\
\text { differentiation by gene } \\
\text { expression }\end{array}$ & \multirow{2}{*}{$\begin{array}{l}\text { Osteoprotective } \\
\text { action }\end{array}$} \\
\hline & $\begin{array}{l}\text { In vivo } \\
\text { Rats }\end{array}$ & $\begin{array}{l}\text { CH 150; } 500 \mathrm{mg} / \\
\mathrm{kg} / \text { weight/day } \\
12 \text { weeks } \\
\text { Vertebrae, lumbars }\end{array}$ & $\begin{array}{l}\text { Increase of bone mineral } \\
\text { density }\end{array}$ & \\
\hline Clark et al. ${ }^{34}$ & $\begin{array}{l}\text { Humans: } \\
147 \text { athletes }\end{array}$ & $\begin{array}{l}\mathrm{CH} 10 \mathrm{~g} \\
\text { placebo (xanthan } \\
\text { gum) } \\
\text { Inflammation, } \\
\text { mobility and joint } \\
\text { pain }\end{array}$ & $\begin{array}{l}\text { Significant improvement } \\
\text { in pain } \\
\text { (knee arthralgia) }\end{array}$ & $\begin{array}{l}\text { Reduction of } \\
\text { pain, protection } \\
\text { of cartilage }\end{array}$ \\
\hline Sugihara et al. ${ }^{37}$ & $\begin{array}{l}\text { Humans: } \\
\text { five individuals }\end{array}$ & $\begin{array}{l}\text { CH } 8 \text { g } \\
\text { Blood samples } 0,5 ; \\
1 ; 2 ; 4 \text { hours } \\
\text { Pro-Hyp; Hyp-Gly }\end{array}$ & $\begin{array}{l}\text { Increase of AA, di- and } \\
\text { tripeptides in peripheral } \\
\text { blood }\end{array}$ & $\begin{array}{l}\text { Proliferation } \\
\text { and cell growth, } \\
\text { as well as } \\
\text { protection of } \\
\text { cartilage }\end{array}$ \\
\hline Hartog et al. ${ }^{38}$ & Rats & $\begin{array}{l}\mathrm{CH} 12,5 ; 25 ; 50 \mathrm{mg} \\
\text { Three consecutive } \\
\text { days } \\
\text { Induced } \\
\text { inflammation in } \\
\text { the ear } \\
\text { Blood sample }\end{array}$ & $\begin{array}{l}\text { Higher concentration } \\
\text { of glycine in plasma; } \\
\text { swelling reduction; } \\
\text { proinflammatory } \\
\text { cytokines }\end{array}$ & $\begin{array}{l}\text { Potential } \\
\text { reduction in } \\
\text { pain (hip and } \\
\text { knee) }\end{array}$ \\
\hline Shigemura et al. ${ }^{39}$ & $\begin{array}{l}\text { Humans: } \\
\text { Healthy } \\
\text { volunteers } \\
\mathrm{n}=4\end{array}$ & $\begin{array}{l}\text { Different doses } \\
\text { of } \mathrm{CH} / \mathrm{kg} / \text { weight } \\
(30,8 ; 153,8 ; 384,6 \\
\mathrm{mg} / \mathrm{kg} / \text { weight } \\
\text { Blood sample } \\
\text { before, } 15,30, \\
60,120,240,360 \\
\text { minutes after } \\
\text { ingestion }\end{array}$ & $\begin{array}{l}\text { Dose-dependent increase } \\
\text { of } 6.43 ; 20.17 ; 32.84 \\
\text { nmol/mL in the plasma } \\
\text { concentration of Hyp, } \\
\text { respectively. }\end{array}$ & $\begin{array}{l}\text { Increase of } \\
\text { Hp in plasma } \\
\text { and potential } \\
\text { of increase in } \\
\text { amino acid } \\
\text { absorption }\end{array}$ \\
\hline Bruyère et al. ${ }^{40}$ & $\begin{array}{l}\text { Humans: } \\
200 \text { patients } \\
\text { older than } 50 \\
\text { years of age }\end{array}$ & $\begin{array}{l}\text { CH } 12 \text { g } \\
\text { Placebo (gel } \\
\text { capsules) }\end{array}$ & $\begin{array}{l}6 \text { month treatment, } \\
\text { improvement in symptoms } \\
\text { according to EVA-D scale; } \\
\text { tolerability }\end{array}$ & $\begin{array}{l}\text { Efficacy and } \\
\text { safety of } \\
\text { supplementation }\end{array}$ \\
\hline
\end{tabular}




\section{DISCUSSION}

Due to the progressive decrease in adaptive responses to environmental factors in elderly bodies, it is possible that aging is accompanied by chronic diseases that often require continuous treatment, causing functional limitations and some level of dependency. In several countries the elderly population receives new forms of treatment, as well as preventive care that fits the profile of the elderly individual in order to avoid unnecessary hospitalizations and thus consequent increases in health spending. ${ }^{8}$ Alves et al. ${ }^{9}$ points out that the aging process is not directly related to incapacitating diseases, but that chronic diseases are often associated with the effects of age.

Due to being asymptomatic, OP is often underdiagnosed and undertreated. The consequences of osteoporotic fractures include increased morbidity and mortality and an impact on social, emotional and financial quality of life. Among the fractures with greatest impact on mobility, the hip is considered the most devastating type of osteoporotic fracture, as in addition to loss of mobility, it increases the need for long-term care. Other types of fractures can also cause impact on quality of life, such as multiple or severe vertebral fractures, which are associated with significant pain; reduced lung function; decreased stature and kyphosis, which can restrict movement and increase the risk of further falls and fractures. ${ }^{10}$ Bone is a complex mineralized tissue, whose main function is to resist mechanical forces. It presents specific characteristics, not only in the amount of bone tissue, but also its qualities, specifically the geometry and shape, trabecular microarchitecture, deposition of minerals and quality of collagen in the organic matrix. ${ }^{11}$

$\mathrm{OA}$ is a degenerative joint disease characterized mainly by a slow and gradual destruction of cartilage with a narrowing of joint space, osteophyte formation and bone sclerosis synovitis ${ }^{12,13}$ and its exact cause is still unknown. ${ }^{14}$ It usually affects middle-aged adults and although it is one of the main causes of chronic disability, conventional therapeutic treatments are still limited, as their results are minimal, and prolonged use of these drugs can cause toxicity. As a result, the dietary supplement industries are increasingly investing in the development of supplements in order to delay the disease by directly supplying natural compounds, in order to inhibit or enhance the role of biological mediators to preserve the structural integrity of the joint. ${ }^{15}$

The collagen molecule is composed of a repeating sequence of three amino acids (Gly$\mathrm{X}-\mathrm{Y}$ ), where Gly is glycine; $\mathrm{X}$ is often proline, and $\mathrm{Y}$ is hydroxyproline or hydroxylysine. In general, collagen contains about $30 \%$ glycine, $12 \%$ proline, $11 \%$ alanine, $10 \%$ of hydroxyproline and $1 \%$ of hydroxylysine. From a nutritional point of view, collagen is considered an inferior quality protein, as there is a predominance of the described amino acids and minimal or no amounts of most of the essential amino acids such as tryptophan, methionine, cystine and tyrosine ${ }^{16}$ Nevertheless, it has nutritional value because of its atypical amino acid profile which stimulates the synthesis of collagen in cartilage and the extracellular matrix of other tissues. ${ }^{17}$

Collagen, as well as other ingested proteins such as collagen, is not absorbed. Most protein digestion, approximately $80 \%$, occurs in the duodenum and jejunum and is caused by the action of the pancreatic juice, while only $10-20 \%$ occurs in the stomach, due to hydrochloric acid and pepsin. Luminal hydrolysis of proteins and polypeptides in free amino acids (AA) and short peptides occurs in the small intestine through the action of enteropeptidase. This process, at neutral $\mathrm{pH}$, activates trypsinogen and trypsin, which, in turn, promotes the activation of other propeptidases in the pancreatic juice. The AA and small peptides are hydrolyzed by brush border peptidases into AA, dipeptides and tripeptides, which are mainly absorbed at the proximal jejunum 
by simple diffusion, facilitated diffusion or active transference by co-transport. AA peptides are intended to perform numerous functions, including the synthesis of collagen itself. ${ }^{18}$ Experiments with mice performed by Oesser et al., ${ }^{19}$ to quantify the distribution of radioactive collagen peptides, indicated that after intestinal absorption, peptides derived from $\mathrm{CH}$ accumulate preferentially in cartilage and bone.

In connective tissue, type I collagen or tropocollagen is the most abundant, and a source of partially hydrolyzed collagen (gelatin) and collagen hydrolysate. The difference between the collagen hydrolysate and gelatin is that the collagen hydrolysate is dissolved in water or brine thus making its digestion and absorption easier, allowing the production of collagen by the body from the free amino acids. ${ }^{20}$ The most important feature of collagen hydrolysate is the prevalence of glycine and proline in its composition. These amino acids are essential for the stability and regeneration of cartilage. $^{21}$

Although $\mathrm{OA}$ and $\mathrm{OB}$ are diseases related to skeletal disorders, epidemiological surveys rarely associate one disease with the other. Rather, the presence of one can be considered a protective factor for the other, because the increase of bone conformity in OP can maintain and preserve the articular cartilage. While there are few reports on OA in its initial stage, recent studies have reported severe microscopic changes in bone cartilage in advanced stages of $\mathrm{OA}$, such as an increase in the volume of subchondral bone, low bone mineralization and mechanical strength, as well as considerable deterioration in articular cartilage. This suggests a correlation of development of $\mathrm{OA}$ in patients with OP, which also means that OP treatment can help prevent the progression of OA. ${ }^{22,23}$

A study carried out by Hays et al. ${ }^{24}$ tested the supplementation of women aged between 65 and 85 years. The nitrogen balance was compared following supplementation with two protein compounds, "whey protein" and collagen hydrolysate. Although the amount of protein was the same for both supplements, the women who consumed the whey-based supplement experienced a decrease in body weight without a change in body profile, suggesting a loss of lean body mass, whereas the women who ingested the collagen supplement experienced no significant changes in body weight. Furthermore, nitrogen excretion was lower with the collagen hydrolysate than with the whey, thus maintaining nitrogen balance and lean body mass. Also according to Hays et al. ${ }^{24}$ the study data, combined with previous estimates of protein requirements in the diet of older people, strongly indicate that the current recommended dietary intake (RDA) may be inadequate or marginal, even in normocaloric diets. They also noted that although collagen hydrolysate is deficient in essential amino acids, combining it with a diet featuring adequate amounts of protein could promote nitrogen balance.

According to Takeda et al., ${ }^{25}$ type I collagen represents $25 \%$ of the total body protein and $80 \%$ of connective tissue in humans. The synthesis of type I collagen also plays an important role in osteoblast differentiation, enhancing bone mineral density, bone mineral content and increasing the amount of type I collagen in the bone matrix.

Bone loss is due to an imbalance between bone formation and resorption, especially in women after menopause. This imbalance is characterized by excessive activity of osteoclasts on osteoblasts, leading to increased bone remodeling. According to Guillerminet et al., ${ }^{26}$ in order for the effect of collagen administration to be positive, the collagen must be hydrolyzed. In their in vivo studies on mice, they noted that proteins are essential for bone health and prevention of OP. The collagen modulates bone formation and mineralization of bone matrix with increased growth and differentiation of osteoblastic cells and reduction of osteoclastic cells. All collagens tested were able to increase the osteoblast activity. These results and previous observations show that the structure and amount of peptides derived from collagen after oral administration depends, not only on the collagen source, but also the molecular size of the collagen hydrolysate, suggesting that not all the collagen molecule interacts with bone cells. 
Jackix et al. ${ }^{27}$ noted that collagen hydrolysate contributed to bone conservation, composition and strength. This study ${ }^{27}$ evaluated the result of collagen application in order to counteract the effects of ovariectomy on bone mass, biomechanical strength, protein content and serum osteocalcin levels in six groups of eight rats: three ovariectomized groups, one negative control group that had undergone sham surgery, and two intact groups. One month after surgery, the rats received a diet supplemented with gelatin (control) or CH on two levels, (1) an amount equal to five times the recommended amount for humans ( $10 \mathrm{~g} / \mathrm{day})$, and the other (2) with levels ten times higher, all according to the following criteria: two intact groups, gelatin and $\mathrm{CH}$ (ten times); three ovariectomized groups, gelatin, $\mathrm{CH}$ (five times) and $\mathrm{CH}$ (ten times); a group of sham $\mathrm{CH}$ (ten times). After eight weeks, samples of the femur, spine and blood were evaluated. The group that received the highest dose of $\mathrm{CH}$ withstood four times as much load, in addition to having the highest percentage of bone protein, mineral content and osteocalcin content among the groups. The group with the highest level of supplementation (OVX$\mathrm{CH} 10)$ showed divergence in levels of osteocalcin. In terms of the alkaline phosphatase results, an increase was identified in this group, but the relevance of this study was limited because the increased alkaline phosphatase may be associated with enzyme activity, as a compensatory reaction to the surgery.

A study by Kim et al. ${ }^{28}$ considered bone loss to be a non-uniform process because the cancellous bone, the main component of the vertebrae, represents a higher risk than the cortical bone, the main component of the femur. Therefore, the lumbar vertebrae play a key role in monitoring OP. In this study, the authors demonstrated the functional effects of collagen hydrolysate in vitro and in vivo. In the in vitro tests, it was observed that $\mathrm{CH}$ enhances osteoblastic differentiation in human cells via the expression of the COL1A1 gene involved in the synthesis of collagen; in the in vivo tests, a significant increase in bone mineral density in the lumbar vertebrae was found, just like within the bodies of ovariectomized rats (OVX) treated for 12 weeks with diets containing $0.3 \%$ and $1 \% \mathrm{CH} 150 \mathrm{mg} / \mathrm{kg}$ and $500 \mathrm{mg} / \mathrm{kg}$. These results suggest that $\mathrm{CH}$ exercises an osteoprotective action, highlighting it as a potential therapeutic alternative for the treatment and prevention of OP. High levels of bone markers in OVX rats can mask the effects of treatment with additional $\mathrm{CH}$. In addition, measurements at a single time point may not determine subtle effects between the treatment and responses of bone markers.

The positive effect of the protein on bone formation is related to the composition, or in other words $50 \%$ of the bone is formed by collagen and the other half by calcium. Therefore, an unsuitable diet, not only in calcium, but also in protein would hinder bone reconstruction. ${ }^{29}$

Rezende \& $\mathrm{Gobbi}^{30}$ and Rezende \& Campos ${ }^{31}$ highlight in their research a cause other than aging for OA, whose therapeutic proposal would cover all aspects of the disease. The pathogenesis of OA comes from inflammatory and mechanical factors: inflammatory, in responses mediated by chondrocytes and synovitis; mechanical, associated with the movement and physical strength that is especially concentrated in joints. OA would result from inflammation of the joints in an attempt to correct abnormal mechanical stress. Still, for Rezende \& Gobbi ${ }^{30}$ and Rezende \& Campos, ${ }^{31}$ inflammatory responses are higher in patients with $\mathrm{OA}$ and enhanced aging, while the mechanical responses comprise a combination of physiological and genetic factors, and in both obesity would be an aggravating factor. Obesity increases the load on the joints and activates the production of proinflammatory adipokine receptors present on the surface of chondrocytes, osteoblasts, and both synovial and subchondral membranes. ${ }^{32}$

Zague et al., ${ }^{33}$ state that there is a consensus that the effects promoted by collagen peptides intake are related to their hydrolyzed form. For the authors, ${ }^{33}$ food supplements and pharmacological $\mathrm{CH}$ are justified because they have beneficial biological functions far beyond the reduction of pain in patients with OA. Besides being involved in the cartilage matrix synthesis, some collagen peptides exhibit both anti-hypertensive and 
cardioprotective activity, through the regulation of nitric oxide as well as the intercellular adhesion molecule and the inhibition of the converting enzyme of angiotensin I, along with antioxidant activities in different oxidation systems.

Clark et al. ${ }^{34}$ monitored 147 athletes for 24 weeks. Although there was no evidence of joint disease, this was considered to be a high risk group. The subjects were divided into two groups, one receiving a formulation containing $25 \mathrm{ml}$ of liquid that contained $10 \mathrm{~g}$ of collagen hydrolysate, and another group receiving a placebo consisting of $25 \mathrm{ml}$ of liquid with xanthan gum. Parameters including inflammation, mobility and joint pain; pain whilst walking, standing, the joints in a state of rest, carrying objects and lifting were evaluated. There was significant improvement in the group supplemented with collagen hydrolysate in terms of pain, in all evaluated parameters, especially in the subgroup with knee arthralgia.

Oesser \& Seifert ${ }^{35}$ suggest that collagen hydrolysate stimulates collagen biosynthesis in chondrocytes, articular cells responsible for the synthesis, maintenance and organization of the ECM extracellular matrix. Changes in the ECM composition provoke collagen turnover which stimulates chondrocyte activity, inducing synthesis and continued remodeling. Based on their experiments and a literature review, Bello \& Oesser ${ }^{36}$ concluded that collagen hydrolysate administered orally may accumulate in the cartilage as well as stimulate significant increase in the synthesis of ECM macromolecules by chondrocytes.

With the assumption that certain amino acids play active roles in bone tissue, Sugihara et al. ${ }^{37}$ accessed the levels of hydroxyproline (Pro-Hyp) and glycine hydroxyl (Hyp-Gly) present in the blood of five healthy subjects following oral ingestion of $\mathrm{CH}$. Volunteers ingested $8 \mathrm{~g}$ of $\mathrm{CH}$ dissolved in $100 \mathrm{ml}$ of water and blood samples were collected before; 30 minutes, and 1, 2 and 4 hours after ingestion. The concentration of Hyp-Gly and Pro-Hyp in plasma reached its peak after an hour at a proportion of $6.3 \%$ to $22.1 \%$, respectively. After oral ingestion of $\mathrm{CH}$, not only amino acids, but also di- and tripeptides are assimilated and remain for a relatively long time in human peripheral blood. It is estimated that these peptides promote cell proliferation and growth, hyaluronic acid synthesis in cultured dermal fibroblasts and synovial cells as well as the chondroprotective effect on articular cartilage. A limitation of this study is the lack of standardization in relation to sports activities. Better results could be obtained with the inclusion of athletes engaged in sports such as soccer or basketball.

In order to evaluate the anti-inflammatory potential of glycine, Hartog et al..$^{38}$ administered $\mathrm{CH}$ in different amounts, leading to ear inflammation in mice. $\mathrm{CH}$ was administered daily by oral gavage in the following amounts: control (0); 12.5, 25 and $50 \mathrm{mg}$ for three consecutive days, and inflammation was induced on the third day by the intra-dermal injection of zymosan. The plasma levels of glycine, in the collected blood samples, increased in accordance with the concentration of applied $\mathrm{CH}$, suggesting its ability to neutralize locally induced inflammation, according to the reduction in ear edema, as well as reducing the production of IL-6, and lipopolysaccharide (LPS). Glycine is a non-essential amino acid found in many different proteins and is one of the major structural units of collagen, amounting to about $30 \%$ of the amino acids. The effects of glycine in inhibiting proinflammatory cytokine expression have been studied in vitro and confirmed in different animal models, especially for beneficial effects in reducing pain in OA of the hip and knee. ${ }^{38}$

Apart from glycine, there is a relation between the intake of collagen and hydroxyproline levels in human plasma. Hydroxyproline is an amino acid specifically present in collagen, and studies ${ }^{39}$ have shown that its presence in the plasma inhibits mineralization chondrocytes and modulates the expression of the RUNX1 gene (runt-related transcription factor 1) and osteocalcin, stimulates the production of hyaluronic acid in the synovial cell cultures and increases the production of skin fibroblasts in rats.

To estimate the effective dose for beneficial effects on human health, Shigemura et al..$^{39}$ dosed the concentration of Hyp in human plasma from 
different doses of $\mathrm{CH}$ with one week intervals between each ingestion. Four healthy adults with a mean age of 27 years, ingested 2, 10, and $25 \mathrm{~g}$ per $65 \mathrm{~kg}$ of body weight of $\mathrm{CH}$ and venous blood samples were collected before, 15, 30, 60, 120, 240 and 360 minutes after administration. According to the analyzes, the concentration of Hyp peptide increased in a dose-dependent manner 30 minutes after ingestion and reached its maximum level after two hours, and although the Hyp level reduced to two thirds of its maximum level six hours after ingestion, it was still significantly higher than before the administration of $\mathrm{CH}$. The results showed that larger doses of $\mathrm{CH}$ cause increases in the concentration of Hyp in plasma, as well as heightening the absorption potential of the amino acids.

Bruyère et al. ${ }^{40}$ evaluated the efficacy and safety of $\mathrm{CH}$ supplementation in a randomized doubleblind study with 200 patients of both genders, aged 50 years or older, and who suffered from joint pain. For six months half of the group of subjects received a daily dose equivalent to $1,200 \mathrm{mg}$ of $\mathrm{CH}$ and the other half received a placebo (gel cap). In terms of safety and tolerability, there was no difference between the placebo group and the $\mathrm{CH}$ group. As for the clinical response, by the third month of treatment there was no significant difference, however, in the sixth month, the improvement was significantly higher in the group that ingested the $\mathrm{CH}$ capsules.

Despite the great expectations for the positive results of studies such as Bello \& Oesser, ${ }^{36}$ Schadow et al., ${ }^{41}$ concluded in their clinical trials with radioactive proline in vitro models that even at high doses $(10 \mathrm{mg} / \mathrm{ml})$, collagen does not exert

\section{REFERENCES}

1. Gottlie MGV, Carvalho D, Schneider RH, Cruz IBM. Aspectos genéticos do envelhecimento e doenças associadas: uma complexa rede de interações entre genes e ambiente. Rev Bras Geriatr Gerontol [Internet] 2007 [acesso em 19 fev. 2014];10(3): 273-83. Disponível em: http://revista.unati.uerj. br/scielo.php?script $=$ sci_arttext\&pid=S1809$98232007000300002 \& \operatorname{lng}=$ pt\&nrm $=$ iso a stimulatory effect on collagen biosynthesis by human cartilage, regardless of the degree of change in OA. Different results can occur between studies because of differences in applied analytical methods, species, and the age and health of the joints. Furthermore, the determination of the radioactive proline incorporation rate without specific separation of total proteins does not reflect the true collagen synthesis rate, since the proline enrichment in the collagen compared to other proteins is not described. However Schadow et al. ${ }^{41}$ stated that collagen hydrolysate preparations could contain therapeutically active peptides, but extensive studies are needed, as well as clinical trials, before these are applied as nutraceuticals.

\section{CONCLUSION}

Collagen hydrolysate has a positive therapeutic role in osteoporosis and osteoarthritis: potentially increasing bone mineral density, having a protective effect on articular cartilage and, primarily, providing symptomatic relief of pain. Although there is no consensus in the scientific literature searched on the collagen hydrolysate dosage to be administered, it was noted that with a daily supplementation of $8 \mathrm{~g}$ there was an increase in glycine and proline concentration in plasma. Also, daily doses equivalent to $12 \mathrm{~g}$ promoted a significant improvement in the symptoms of osteoarthritis and osteoporosis. However, further studies are needed to determine the pathogenic factors involved in osteoporosis and osteoarthritis, its early diagnosis, and from which stage of life it would be recommended to start supplementation, as well as the suitable dosage, in order to achieve significant therapeutic potential.

2. Casado 1, Vianna 1M, Thulerl CS. Fatores de risco para doenças crônicas não transmissíveis no Brasil: uma revisão sistemática. Rev Bras Cancerol [Internet] 2009 [acesso em 5 mar. 2014];55(4):379-88. Disponível em: http://www.inca.gov.br/rbc/n_55/ v04/pdf/379_revisao_literatura1.pdf 
3. Inderjeeth CA, Poland KE. Management of osteoporosis in older people. J Pharm Pract Res [Internet] 2010 [acesso em 16 fev. 2014];40(3):22934. Disponível em: http://jppr.shpa.org.au/lib/ pdf/2010_09/C_Inderjeeth_GT.pdf

4. Henrotin Y, Lambert C, Couchourel D, Ripoll C, Chiotelli E. Nutraceuticals: do they represent a new era in the management of osteoarthritis? A narrative review from the lessons taken with five products. Osteoarthr Cartil [Internet] 2011 [acesso em 16 fev. 2014];19(1):1-21. Disponível em: http://www.oarsijournal.com/article/ S1063-4584(10)00358-4/fulltext

5. Tonge DP, Pearson MJ, Jones SW. The hallmarks of osteoarthritis and the potential to develop personalised disease-modifying pharmacological therapeutics. Osteoarthr Cartil [Internet] 2014 [acesso em 16 fev. 2014];22(5): 609-21. Disponível em: http:// www.oarsijournal.com/article/S1063-4584(14)00996$0 /$ fulltext

6. Franzen JM, Santos JMSR, Zancanaro V. Colágeno: uma abordagem para a estética. Rev Interdiscipl Estud Saúde [Internet] 2013 [acesso em 5 mar. 2014];2(2):4961. Disponível em: http://www.uniarp.edu.br/ periodicos/index.php/ries/article/view/161/171

7. Cosgrove MC, Franco OH, Granger SP, Murray PG, Mayes AE. Dietary nutrient intakes and skin-aging appearance among middle-aged American women. Am J Clin Nutr [Internet] 2007 [acesso em 8 jan. 2014];86(4):1225-31. Disponível em: http://ajcn. nutrition.org/content/86/4/1225.long

8. Carneiro IAF, Campino ACC, Leite F, Rodrigues CG, Santos GMM, Silva ARA. Envelhecimento populacional e os desafios para o sistema de saúde brasileiro [Internet] . São Paulo: IESS; 2013. Disponível em: http://www.ibedess.org.br/imagens/ biblioteca/939_envelhecimentopop2013.pdf

9. Alves 1C, Leimann BCQ, Vasconcelos MEL, Carvalho MS, Vasconcelos AGG, Fonseca TCO, et al. A influência das doenças crônicas na capacidade funcional dos idosos do Município de São Paulo, Brasil. Cad Saúde Pública [Internet] 2007 [acesso em 19 jan 2014];23(8):1924-30. Disponível em: http://www.scielo.br/scielo.php?script=sci_ arttext\&pid=S0102-311X2007000800019

10. Lewiecki EM. Current and emerging pharmacologic therapies for the management of postmenopausal osteoporosis. J Women's Health [Internet] 2009 [acesso em 22 fev 2014];18(10):1615-26. Disponível em: http://online.liebertpub.com/doi/ pdfplus/10.1089/jwh.2008.1086
11. Lotz M, Martel-Pelletier J, Christiansen C, Brandi ML, Bruyère O, Chapurlat R, et al. Value of biomarkers in osteoarthritis: current status and perspectives. Ann Rheum Dis [Internet] 2013 [acesso em 1 maio 2014];72(11):1756-63. Disponível em: http://www.ncbi.nlm.nih.gov/pmc/articles/ PMC3812859

12. Staines KA, Pollard AS, Mcgonnell IM, Farquharson C, Pitsillides AA. Cartilage to bone transitions in health and disease. J Endocrinol [Internet] 2013 [acesso em 15 maio 2014];219(1):1-12. Disponível em: http://www.ncbi.nlm.nih.gov/pmc/articles/ PMC3769078/

13. Suantawee T, Tantavisut S, Adisakwattana S, Tanavalee A, Yuktanandana P, Anomasiri W, et al. Oxidative stress, vitamin E, and antioxidant capacity in knee osteoarthritis. J Clin Diagn Res [Internet] 2013 [acesso em 30 de maio 2014];7(9):1855-9.

Disponível em: http://www.ncbi.nlm.nih.gov/pmc/ articles/PMC3809620/

14. Vermeij EA, Koenders ML, Blom AB, Arntz OJ, Bennink MB, Van Den Berg WB, et al. In vivo molecular imaging of cathepsin and matrix metalloproteinase activity discriminates between arthritic and osteoarthritic processes in mice. Mol Imaging 2014;13(2):1-10.

15. Vista ES, Lau CS. What about supplements for osteoarthritis?: A critical and evidenced-based review. Int J Rheum Dis 2011;14(2):152-8.

16. Prestes RC. Colágeno e seus derivados: características e aplicações em produtos cárneos. UNOPAR Cient Ciênc Biol Saúde [Internet] 2013 [acesso em jan. 2014];15(1):65-74. Disponível em: http://bases.bireme. $\mathrm{br} /$ cgi-bin/wxislind.exe/iah/online/?IsisScript=iah/ iah. $x$ is\&src $=$ google\&base $=$ LILACS\&lang $=p \&$ next Ac tion=lnk\&exprSearch $=661307 \&$ indexSearch $=$ ID

17. Roman JA, Sgarbieri VC. Caracterização físicoquímica do isolado protéico de soro de leite e gelatina de origem bovina. Braz J Food Technol [Internet] 2007 [acesso em 19 jan. 2014];10(2):137-43. Disponível em: http://www.sncsalvador.com.br/artigos/ caracterizaco-fisico-quimica-isolado-proteico-sorode-leite-gelatina-bovina.pdf

18. Frenhani PB, Burini RC. Mecanismos de absorção de aminoácidos e oligopeptídios. Controle e implicações na dietoterapia humana. Arq Gastroenterol [Internet] 1999 [acesso jan. 2014];36(4):227-37. Disponível em: http://www.scielo.br/scielo.php?script=sci_arttext\&p id=S0004-28031999000400011 
19. Oesser S, Adam M, Babel W, Seifert J. Oral administration of $14 \mathrm{C}$ labeled gelatin hydrolysate leads to an accumulation of radioactivity in cartilage of mice (C57/BL). J Nutr [Internet] 1999 [acesso em 19 de jan. 2014];129(10):1891-5. Disponível em: http:// jn.nutrition.org/content/129/10/1891.full.pdf+htm

20. Prestes RC, Golunski SM, Toniazzo G, Kempka AP, DiLuccio M. Caracterização da fibra de colágeno, gelatina e colágeno hidrolisado. Rev Bras Prod Agroindustr [Internet] 2013 [acesso em 5 maio 2014];15(4):375-82. Disponível em: http://www.deag. ufcg.edu.br/rbpa/rev154/Art1546.pdf

21. Silva TF, Penna ALB. Colágeno: características químicas e propriedades funcionais. Rev Inst Adolfo Lutz [Internet] 2012 [acesso em 3 maio 2014];71(3):530-9. Disponível em: http://revistas.bvsvet.org.br/rialutz/article/view/5336/4600

22. Bobinac D, Marinovic M, Bazdulj E, Cvijanovic O, Celic T, Maric I, et al. Microstructural alterations of femoral head articular cartilage and subchondralbone in osteoarthritis and osteoporosis. Osteoarthr Cartil [Internet] 2013 [acesso em 16 maio 2014];21(11):172430. Disponível em: http://www.oarsijournal.com/ article/S1063-4584(13)00866-2/fulltext

23. Kamimura M, Nakamura Y, Ikegami S, Mukaiyama K, Uchiyama S, Kato K. The pathophysiology of primary hip osteoarthritis may originate from bone alterations. Open Rheumatol J [Internet] 2013 [acesso em 15 maio 2014];7: 112-8. Disponível em: http:// www.ncbi.nlm.nih.gov/pmc/articles/PMC3866704/

24. Hays NP, Kim H, Wells AM, Kajkenova O, Evans WJ. Effects of whey and fortified collagen hydrolysate protein supplements on nitrogen balance and body composition in older women. J Am Diet Assoc 2009;109(6):1082-87.

25. Takeda S, Jong-Hoon P, Kawashima E, Ezawa I, Omi N. Hydrolyzed collagen intake increases bone mass of growing rats trained with running exercise. J Int Soc Sports Nutr [Internet] 2013 [acesso em 6 maio 2014];10(35). Disponível em: http://www.jissn.com/ content/pdf/1550-2783-10-35.pdf

26. Guillerminet F, Beaupied H, Fabien-SouléV, Tomé D, Benhamou CL, Roux C, et al. A. Hydrolyzed collagen improves bone metabolism and biomechanical parameters in ovariectomized mice: an in vitro and in vivo study. Bone 2010;46(3):827-34.

27. Jackix EA, Cúneo F, Amaya-Farfan J, Assunção JV, Quintaes KD. A food supplement of hydrolyzed collagen improves compositionaland biodynamic characteristics of vertebrae in ovariectomizedrats. J Med Food 2010;13(6):1-6.
28. Kim HK, Kim MG, Leem KH. Osteogenic activity of collagen peptide via ERK/MAPK pathway mediated boosting of collagen synthesis and its therapeutic efficacy in osteoporotic bone by backscattered electron imaging and microarchitecture analysis. Molecules [Internet] 2013 [acesso em 15 maio 2014];18(12):15474-89. Disponível em: http:// www.mdpi.com/1420-3049/18/12/15474

29. Montilla RNG, Aldrighi JM, Marucci MFN. Relação cálcio/proteína da dieta de mulheres no climatério. Rev Assoc Med Bras [Internet] 2004 [acesso em 5 maio 2014];50(1):52-4. Disponível em: http://www.scielo.br/scielo.php?pid=S010442302004000100035\&script=sci_arttext

30. Rezende MU, Gobbi RG. Tratamento medicamentoso da osteoartrose do joelho. Rev Bras Ortop [Internet] 2009 [acesso em 8 maio 2014];44(1):14-9. Disponível em: http://www.scielo.br/scielo.php?pid=S010236162009000100002\&script=sci_arttext

31. Rezende UM, Campos GC. A osteoartrite é uma doença mecânica ou inflamatória? Rev Bras Ortop [Internet] 2013 [acesso em 1 maio 2014];48(6):471-4. Disponível em: http://www.rbo.org.br/PDF/48-6port/07-87.pdf

32. King IK, March I, Anandacoomarasamy A. Obesity \& osteoarthritis. Indian J Med Res [Internet] 2013 [acesso em 15 maio 2014];138(2);185-93. Disponível em: http://www.ncbi.nlm.nih.gov/pmc/articles/ PMC3788203/

33. Zague V, Freitas V, Rosa MC, Castro GA, Jaeger RG, Santelli GM. Collagen hydrolysate intake increases skin collagen expression and suppresses matrix metalloproteinase 2 activity. J Med Food [Internet] 2011 [acesso em 6 maio 2014];14(6):618-24. Disponível em: http://online.liebertpub.com/doi/abs/10.1089/ jmf.2010.0085

34. Clark KL, Sebastianelli W, Flechsenhar KR, Aukermann DF, Meza F, Millard RL, et al. 24-Week study on the use of collagen hydrolysate as a dietary supplement in athletes with activity-related joint pain. Curr Med Res Opin 2008;24(5):1485-96.

35. Oesser S, Seifert J. Stimulation of type II collagen biosynthesis and secretion in bovine chondrocytes cultured with degraded collagen. Cell Tissue Res 2003;311(3):393-9.

36. Bello AE, Oesser S. Collagen hydrolysate for the treatment of osteoarthritis and other joint disorders: a review of the literature. Curr Med Res Opin 2006;22(11):2221-32. 
37. Sugihara F, Inoue N, Kuwamori M, Taniguchi M. Quantification of hydroxyprolyl-glycine (Hyp-Gly) in human blood after ingestion of collagen hydrolysate. J Biosci Bioeng 2012;113(2):202-3

38. Hartog A, Cozijnsen M, Vrij G, Garssen J. Collagen hydrolysate inhibits zymosan-induced inflammation. Exp Biol Med 2013;238(7):798-802.

39. Shigemura Y, Kubomura D, Sato Y, Sato K. Dose dependent changes in the levels of free and peptide forms of hydroxyproline in human plasma after collagen hydrolysate ingestion. Food Chem [Internet] 2014 [acesso em 16 maio 2014];159:328-32. Disponível em: http://www.sciencedirect.com/science/article/ pii/S0308814614002763
40. Bruyère $O$, Zegels B, Leonori I, Rabenda V, Janssen A, Bourges C, Reginster JY. Effect of collagen hydrolysate in articular pain: A 6-month randomized, double-blind, placebo controlled study. Complement Ther Med [Internet] 2012 [acesso em 16 maio 2014];20(3):124-30. Disponível em: http://www. complementarytherapiesinmedicine.com/article/ S0965-2299(12)00002-7/fulltext

41. Schadow S, Siebert HC, Lochnit G, Kordelle J, Rickert M, Steinmeyer J. Collagen metabolism of human osteoarthritic articular cartilage as modulated by bovine collagen hydrolysates. PLoSOne [Internet] 2013 [acesso em 1 maio 2014];8(1). Disponível em: http://www.plosone.org/article/ info $\% 3$ Adoi $\% 2 F 10.1371 \% 2 F j o u r n a l . p o n e .0053955$

Received: 30 September, 2014

Reviewed: 28 May, 2015

Accepted: 5 August, 2015 